\title{
INTERDEPENDENCE ASSESSING FOR NETWORKED READINESS INDEX ECONOMIC AND SOCIAL INFORMATIVE FACTORS*
}

\author{
Maksym Sitnicki ${ }^{1}$, Iryna Netreba²
}

\begin{abstract}
The purpose of the paper is to identify the common factors and their influence on features of NRI and, as a result, the impact on the competitiveness and well-being of Ukraine. The most influential economic indicators for the similar economic changes in the European countries are determined. Exploratory factor analysis has been used to uncover the underlying structure of relationships between measured variables that constructs the value of the Networked Readiness Index (NRI). Methodology. This research is based on a materials for the Eastern European countries, including Ukraine, Bulgaria, the Czech Republic, Estonia, Latvia, Lithuania, Poland and Romania, which have been used for the numerical evaluation of the data. The selection criterion for these countries is in many respects a similar evolutionary path of market economy development. Exploratory factor analysis (EFA) is used to investigate possible relationships between variables that are unique factors and NRI. In this case, EFA is used to analyze the relationship between Environment subindex (Political and regulatory environment with Business and innovation environment), Readiness subindex (Infrastructure, Affordability and Skills), Usage subindex (Individual usage, Business usage, and Government usage) and Impact subindex (Economic impacts and Social impacts) or observable variables and how it is affected by total summary NRI. As the predefined structure has not been set, EFA is used to measure the underlying factors that affect the variables in the data structure. Selecting factors and variables so as to avoid too much similarity of characteristics is also important. The set of subindexes values is divided on 31 variables corresponding to the reports' data. EFA has been carried out on R programming language for statistical computing by using environment and graphics supported by the R Foundation for Statistical Computing (GNU project). Results. Data dependency estimation for the macroeconomically significant Network Readiness Index has been implemented. It is proposed to construct a space of constituent parameters. Eigenvectors have been obtained for an array of data for the economies of eight European countries, which allow us to estimate the general development trends for macroeconomic decision-making problems. In particular, three complex factors are identified. Practical implications. The vectors determine change of the constructs of the value of the Networked Readiness Index of countries. EFA with dataset rawfl, method is maximum likelihood, diagonals of the correlation matrix are equal to squared multiple correlations. PA test is carried out to compute the eigenvalues for the correlation matrix. The study also made it possible to forecast the pace of development of information technology under the influence of the global viral pandemic COVID 19, which will launch a global economic and social recession. Value/originality. The algorithm proposed in this research is proved improving of discriminating between indicators in construct of the value the Networked Readiness Index.
\end{abstract}

Key words: factor analysis FA, Network Readiness Index (NRI), information technologies, economic impacts, macroeconomics, development trends assessment.

JEL Classification: E17, C38, M38, F62, O31, R11

\footnotetext{
Corresponding author:

${ }^{1}$ Taras Shevchenko National University of Kyiv, Ukraine.

E-mail: maksym.sitnicki@ukr.net

ORCID: http://orcid.org/0000-0002-0452-0404

ResearcherID: X-3756-2018

${ }^{2}$ Taras Shevchenko National University of Kyiv, Ukraine.

E-mail: iranetr@ukr.net

ORCID: https://orcid.org/0000-0001-5586-5405
}

${ }^{*}$ This scientific paper published with support by Visegrad Fund. 


\section{Introduction}

Network Readiness Index (NRI) is called atechnological readiness. Itsvaluemeasures the country's ability to use the capabilities of modern information and communication technologies (ICT). Therefore, the NRI provides useful conceptual framework to evaluate the impact of ICTs at a global level, and to benchmark the ICT readiness and the usage of their economies (INSEAD's Endowment, 2019). The NRI is part of the annual Global Information Technology (GITR) report. This information is published in collaboration with INSEAD. The report contains the most authoritative and comprehensive assessments of the impact of ICTs on the competitiveness and well-being of countries (Bilbao-Osorio, Dutta, and Lanvin, 2013).

We have tried to evaluate value of impact of ICT on the competitiveness of Ukraine and to compare with the competitiveness of nations. So composite of three data components is used for research work. Among them, there is the countries' base that is environment offered by a country for ICT including market, political, regulatory approaches, the country's readiness to use ICT including evaluation of the country's individuals, businesses, and governments participants, the usage of amount of ICT.

Since ICTs stimulate business activity and have a leading influence on the innovations' development, increasing of productivity and competitiveness, that thereby determinate the competitiveness and wellbeing of countries. Our research is not based on the specific model and uses common idea that there are close relationship between the countries' level of ICTs development and economic well-being of counties. We have been more interested in identifying the common factors impact on the competitiveness and well-being of Ukraine. Therefore, NRIs are expressed as a function of common factors, unique factors, and errors of evaluation.

In a post-industrial society, the digital economy is a basic category that determines the current state and future growth of the countryin thelong run. Fundamental transformation processes are a powerful generator of new ideas, products, services. Improvements in information technology lead to an increase in the amount of data to be processed. It affects the economy, politics, demography, socio-cultural environment, foreign economic relations. The level of development of the country's economy depends on the level of development of information and communication technologies and the degree of their use. Informatization forms the basis for using new business models and enhancing the effectiveness of decision-making. According to statistics, a high level of development of information and communication technologies is observed in countries with a high value of the ratio of the level of gross domestic product to the number of working population (World Bank Open Data, 2016).
Also, such development shapes the activities of research universities, which create innovative solutions. The study (Sitnicki, 2018) has developed an author's view of a model of digital research universities, the development of which will affect the global ranking of the research universities. The paper (Sitnicki, 2018a) has identified the priorities for the development of the EU research universities on the basis of an analysis of the world-class universities' rating indicators, to enhance their innovation potential in an information society environment. The research (Zhylinska, Sitnicki, Vikulova, 2019) develops the author's methodological approach and indicators for conducting a systematic assessment of the innovation potential of research universities, which are the drivers of innovative development of the national economies. The study (Pasieczny, Sitnicki, 2019) revealed a number of organizational discrepancies and mismatches that affect the value of organizations and their ability to grow in an information society environment.

\section{Data and methods for analyzing datasets}

\section{Reports' data}

General data have been obtained as annual editions of the GITR, which point to developing and emerging economies are focusing on innovation as a prerequisite to sustain the high economic growth rates. Against this background, the role of ICT for supporting economic growth and creating highly skilled jobs has attracted such attention and research. There is also a development of the concept that ICTs may accelerate the reorientation of certain economic activities of developing countries. So the ICTs are now widely recognized as an important source of efficiency gains for companies. They are enabling them to optimize their resources and functions that have increased other productive investments. Finally, ICT is also recognized as a key source of innovation, which can lead to an increased economic growth and new sources of high value-added jobs (Bilbao-Osorio, Dutta, and Lanvin, 2013).

The GITR series has been published by the World Economic Forum in partnership with INSEAD and contain ICT advances over the last decade. The various numerical data describes influence of ICT on societal well-being and importance of its diffusion for longterm competitiveness. The Annual Global Information Technology Reports feature the latest results of the NRI, offering an overview of the current state of ICT readiness in the world and including detailed profiles for each economy. For example, the Report 2013 includes data tables with global rankings for the NRI's 54 indicators of 144 economies, accounting for over 98 percent of global Gross Domestic Product (GDP) with a comprehensive data section.

According to the conventional approach to assess the level of development and use of information and 
communication technologies at the macroeconomic level calculate Networked Readiness Index (NRI), which is featured in the reports (Bilbao-Osorio, Dutta, and Lanvin, 2013, 2014; Dutta, Geiger, Lanvin, 2015; Baller, Dutta, and Lanvin, 2016). According to the calculation methodology outlined in (Bilbao-Osorio, Dutta, and Lanvin, 2013), the Networked Readiness Index (NRI) is calculated taking into account four groups of subindices, Table 1 .

Table 1

Significant indicators for digital economy

\begin{tabular}{|l|l|}
\hline \multicolumn{1}{|c|}{ Subindex } & \multicolumn{1}{|c|}{ Indicators } \\
\hline A. Environment subindex & $\begin{array}{l}\text { 1. Political and regulatory } \\
\text { environment (9 indicators) } \\
\text { 2. Business and innovation } \\
\text { environment (9 indicators) }\end{array}$ \\
\hline B. Readiness subindex & $\begin{array}{l}\text { 3. Infrastructure (4 indicators) } \\
\text { 4. Affordability (3 indicators) } \\
\text { 5. Skills (4 indicators) }\end{array}$ \\
\hline C. Usage subindex & $\begin{array}{l}\text { 6. Individual usage (7 indicators) } \\
\text { 7. Business usage (6 indicators) } \\
\text { 8. Government usage (3 indicators) }\end{array}$ \\
\hline D. Impact subindex & $\begin{array}{l}\text { 9. Economic impacts (4 indicators) } \\
\text { 10. Social impacts (4 indicators) }\end{array}$ \\
\hline
\end{tabular}

The reports (Bilbao-Osorio, Dutta, and Lanvin, 2013, 2014; Dutta, Geiger, Lanvin, 2015; Baller, Dutta, and Lanvin, 2016) states that the following principles are taken into account when calculating this index:

1) the current legislation governing these processes plays a crucial role in the effective use of information and communication technologies at the macro and microeconomic levels;

2) the prerequisite for the calculation NRI is the high quality of the use of information and communication technologies, which is ensured by the developed infrastructure and access to the necessary data;

3 ) it is necessary to evaluate the use of information and communication technologies on aggregate indicators in
Table 2

Networked Readiness Index for the European countries for the period from 2013 to 2016

\begin{tabular}{|l|c|c|c|c|}
\hline \multicolumn{1}{|c|}{ Countries } & 2013 & 2014 & 2015 & 2016 \\
\hline Ukraine & 3.9 & 3.9 & 4.0 & 4.2 \\
\hline Bulgaria & 3.9 & 3.9 & 4.0 & 4.1 \\
\hline The Czech Republic & 4.4 & 4.5 & 4.5 & 4.7 \\
\hline Estonia & 5.1 & 5.3 & 5.3 & 5.4 \\
\hline Latvia & 4.4 & 4.6 & 4.7 & 4.8 \\
\hline Lithuania & 4.7 & 4.8 & 4.9 & 4.9 \\
\hline Poland & 4.2 & 4.2 & 4.4 & 4.5 \\
\hline Romania & 3.9 & 3.9 & 4.2 & 4.1 \\
\hline
\end{tabular}

different directions: business sector, population of the country, government;

4) the use of information and communication technologies should be implemented in order to develop improvement strategies at the macroeconomic level.

Materials for the Eastern European countries, including Ukraine, Bulgaria, the Czech Republic, Estonia, Latvia, Lithuania, Poland and Romania, have been used for the numerical evaluation of the data. The selection criterion for these countries is in many respects a similar evolutionary path of market economy development, Table 2.

The data of the countries, given in the Table 2, have been used for the implementation of factor analysis of interdependencies. For each of cited countries data similar to those given in Table 3 for Ukraine, Table 4 for Poland or Table 5 for the Czech Republic have been used.

The use of NRI data allows us to identify external factors that affect the countries' rating and level of use of information technology, as well as to develop measures to improve the processes of information and digital economy development at the state level.

A great deal of research is devoted to the problems of using information and communication technologies in the global environment and the digital economy.

Table 3

Informative Indicators for Ukraine for the period from 2013 to 2016

\begin{tabular}{|l|c|c|c|c|}
\hline \multicolumn{1}{|c|}{ Subindex and Indicators } & 2013 & 2014 & 2015 & 2016 \\
\hline A. Environment subindex & $\mathbf{3 . 5}$ & $\mathbf{3 . 5}$ & $\mathbf{3 . 6}$ & $\mathbf{3 . 8}$ \\
\hline 1st pillar: Political and regulatory environment & 3 & 2.9 & 3 & 3.2 \\
\hline 2nd pillar: Business and innovation environment & 4.1 & 4.1 & 4.2 & 4.3 \\
\hline B. Readiness subindex & $\mathbf{5 . 3}$ & $\mathbf{5 . 5}$ & $\mathbf{5 . 6}$ & $\mathbf{5 . 7}$ \\
\hline 3rd pillar: Infrastructure & 3.8 & 4.1 & 4.7 & 4.7 \\
\hline 4th pillar: Affordability & 6.9 & 6.9 & 6.6 & 6.6 \\
\hline 5th pillar: Skills & 5.3 & 5.5 & 5.6 & 5.6 \\
\hline C. Usage subindex & $\mathbf{3 . 3}$ & $\mathbf{3 . 3}$ & $\mathbf{3 . 4}$ & $\mathbf{3 . 6}$ \\
\hline 6th pillar: Individual usage & 3.2 & 3.5 & 3.7 & 3.9 \\
\hline 7th pillar: Business usage & 3.3 & 3.4 & 3.5 & 3.6 \\
\hline 8th pillar: Government usage & 3.3 & 3.1 & 2.9 & 3.1 \\
\hline D. Impact subindex & $\mathbf{3 . 3}$ & $\mathbf{3 . 2}$ & $\mathbf{3 . 5}$ & 3.7 \\
\hline 9th pillar: Economic impacts & 3.2 & 3.1 & 3.3 & 3.4 \\
\hline 10th pillar: Social impacts & 3.4 & 3.2 & 3.7 & 4.0 \\
\hline
\end{tabular}


Table 4

Informative Indicators for Poland for the period from 2013 to 2016

\begin{tabular}{|l|c|c|c|c|}
\hline \multicolumn{1}{|c|}{ Subindex and Indicators } & 2013 & 2014 & 2015 & 2016 \\
\hline A. Environment subindex & $\mathbf{4 . 1}$ & $\mathbf{4 . 1}$ & $\mathbf{4 . 2}$ & $\mathbf{4 . 2}$ \\
\hline 1st pillar: Political and regulatory environment & 3.8 & 3.8 & 3.8 & 3.9 \\
\hline 2nd pillar: Business and innovation environment & 4.4 & 4.5 & 4.6 & 4.6 \\
\hline B. Readiness subindex & $\mathbf{5 . 3}$ & $\mathbf{5 . 4}$ & $\mathbf{5 . 6}$ & $\mathbf{5 . 8}$ \\
\hline 3rd pillar: Infrastructure & 5.0 & 5.1 & 5.1 & 5.3 \\
\hline 4th pillar: Affordability & 5.6 & 5.8 & 6.2 & 6.6 \\
\hline 5th pillar: Skills & 5.2 & 5.3 & 5.4 & 5.5 \\
\hline C. Usage subindex & $\mathbf{4 . 0}$ & $\mathbf{4 . 1}$ & $\mathbf{4 . 1}$ & $\mathbf{4 . 2}$ \\
\hline 6th pillar: Individual usage & 5.0 & 5.1 & 5.1 & 5.3 \\
\hline 7th pillar: Business usage & 3.4 & 3.5 & 3.6 & 3.6 \\
\hline 8th pillar: Government usage & 3.6 & 3.6 & 3.6 & 3.6 \\
\hline D. Impact subindex & $\mathbf{3 . 4}$ & $\mathbf{3 . 4}$ & $\mathbf{3 . 7}$ & 3.8 \\
\hline 9th pillar: Economic impacts & 3.3 & 3.4 & 3.4 & 3.6 \\
\hline 10th pillar: Social impacts & 3.5 & 3.4 & 4.0 & 4.0 \\
\hline
\end{tabular}

Table 5

Informative Indicators for the Czech Republic for the period from 2013 to 2016

\begin{tabular}{|l|c|c|c|}
\hline \multicolumn{1}{|c|}{ Subindex and Indicators } & 2013 & 2014 & 2015 \\
\hline A. Environment subindex & $\mathbf{4 . 2}$ & $\mathbf{4 . 2}$ & $\mathbf{4 . 3}$ \\
\hline 1st pillar: Political and regulatory environment & 4.1 & 4.0 & 4.1 \\
\hline 2nd pillar: Business and innovation environment & 4.4 & 4.4 & 4.5 \\
\hline B. Readiness subindex & $\mathbf{5 . 0}$ & $\mathbf{5 . 5}$ & $\mathbf{5 . 5}$ \\
\hline 3rd pillar: Infrastructure & 5.9 & 6.0 & 6.1 \\
\hline 4th pillar: Affordability & 4.0 & 5.1 & 5.0 \\
\hline 5th pillar: Skills & 5.1 & 5.3 & 5.3 \\
\hline C. Usage subindex & $\mathbf{4 . 4}$ & $\mathbf{4 . 4}$ & $\mathbf{4 . 3}$ \\
\hline 6th pillar: Individual usage & 5.2 & 5.3 & 5.3 \\
\hline 7th pillar: Business usage & 4.1 & 4.1 & 5.3 \\
\hline 8th pillar: Government usage & 3.8 & 3.7 & 4.2 \\
\hline D. Impact subindex & $\mathbf{4 . 0}$ & $\mathbf{4 . 5}$ & 5.8 \\
\hline 9th pillar: Economic impacts & 3.7 & 3.6 & 3.3 \\
\hline 10th pillar: Social impacts & 4.3 & 4.1 & 3.9 \\
\hline
\end{tabular}

The importance of evaluating indicators for global economic decisions

In (Chmeruk, 2018), a thorough analysis of the level of development of the digital economy in Ukraine compared to the EU countries has been carried out. According to the results of the comparative analysis on the dynamics of the subindices Networked Readiness Index, unequal distribution of implementation and use of information technologies has been found, depending on the industries, economic sectors and the regions studied (Strohmaier, Schuetz, Vannuccini, 2019; Degerli, Autekin, Degerli, 2015). It is noted that the pace of use of information technologies in the financial sector is far ahead of the indicators obtained in the public sector of Ukraine's economy. There is also a significant lag behind the NRI indicators of the European countries with high Income, Upper Middle Income, according to the World Bank (Bilbao-Osorio, Dutta, and Lanvin, 2013). The authors of the study argue that the problem of information technology development is related to the lack of a digital strategy at the macroeconomic level.
According to the results of (Degerli, Autekin, Degerli, 2015; Florenz, 2012; Petkova, Ryabokon, Vdovychenko, 2019) it is also proven that the NRI has a tendency to increase in the countries with high incomes, "Upper Middle Income", "Lower Middle Income". The paper also demonstrates the relationship between the level of use of information technology and diffusion of innovations at the state level.

The report (Digital Economy Report, 2019) has identified the need for state regulation of the introduction of information technology, the development of digital economy development strategy. The strategy should provide for qualitative changes in the economy to reduce the gap in information rates between countries with different levels of income. Developing countries should receive international support for global IT projects, which implies improved legislative framework.

In our view, there is a correlation between some of the data used to calculate subindices and NRIs and other indices used to evaluate the digital economy in 
a globalized environment. It is assumed that the data obtained by the NRI for the EU countries may be related to the following indicators:

(1) The Digital Economy and Society Index (DESI) (Digital Economy Report, 2019; Moroz, 2017). It is an internationally agreed upon composite indicator of the socio-economic development of a country, which allows you to identify investment priorities for the development of information technology and digital economy as a whole.

(2) Digitization Index (Digital Economy Report, 2019; Cámara, Tuesta, 2017). It is an internationally agreed upon composite indicator that allows you to evaluate environmental factors that influence the use of information technology to enhance a country's competitiveness. Obviously, there is a correlation between indices (1) and (2) with the E-government Readiness Index (Mohammeda, Ibrahima, 2013) and The Global Competitiveness Index (Balzaravičienèl, Pilinkiené, 2012).

The basis of this study is the value of the NRI for 20132016 (Bilbao-Osorio, Dutta, and Lanvin, 2013, 2014; Dutta, Geiger, Lanvin, 2015; Baller, Dutta, and Lanvin, 2016), as well as the results of the research described above. Available data from 2013 till 2016 GITRs have been selected for 8 countries such as Bulgaria, the Czech Republic, Estonia, Latvia, Lithuania, Poland, Romania and Ukraine (Bilbao-Osorio, Dutta, and Lanvin, 2013, 2014; Dutta, Geiger, Lanvin, 2015; Baller, Dutta, and Lanvin, 2016).

Factor analysis of the NRI indicators

The base for research is a significant difference of indicators that characterize NRIs of Bulgaria, the Czech

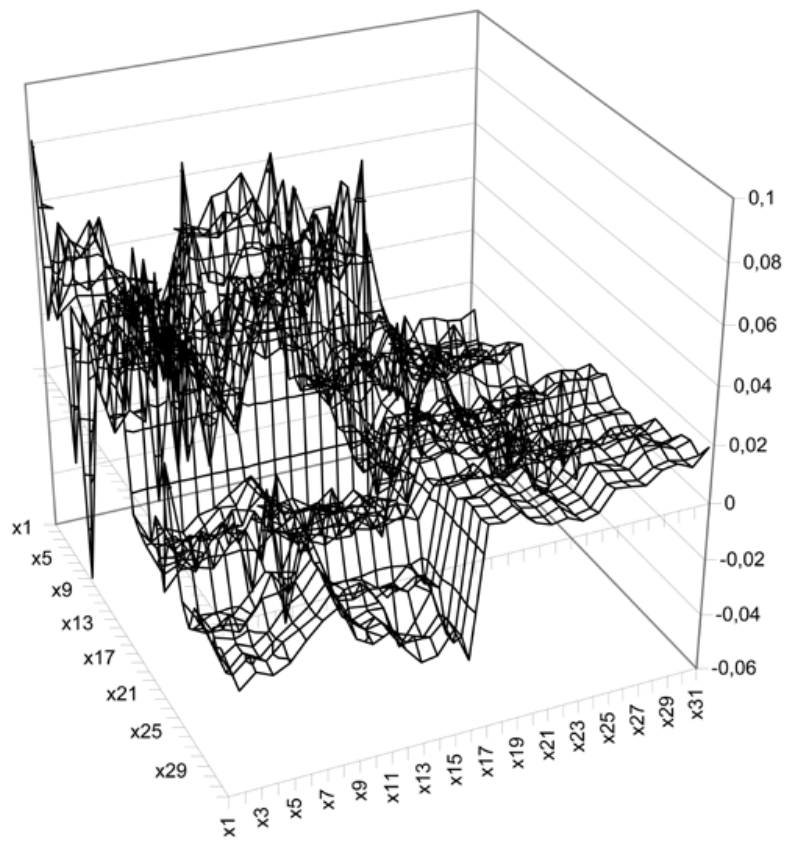

Figure 1. NRI indicators covariation matrix

Source: developed by the authors
Republic, Estonia, Latvia, Lithuania, Poland, Romania and Ukraine. Significant difference has been shown as an example of a simple correlation and covariation matrixes, Figure 1, 2.

\section{Results and discussion}

We have used the exploratory factor analysis (EFA) to investigate possible relationships between variables, which are unique factors and NRI. In our case, EFA is used to analyze the relationship between the Environment subindex (Political and regulatory environment with Business and innovation environment), Readiness subindex (Infrastructure, Affordability and Skills), Usage subindex (Individual usage, Business usage, and Government usage) and Impact subindex (Economic impacts and Social impacts), or observable variables and how it is affected by total summary NRI. As predefined structure has not been set, EFA is used to measure the underlying factors that affect the variables in a data structure. Selecting factors and variables so as to avoid too much similarity of characteristics is also important. The set of subindexes values is divided on 31 variables corresponding to the reports' data. EFA has been carried out on R programming language for statistical computing by using environment and graphics supported by the R Foundation for Statistical Computing (GNU project) (The $\mathrm{R}$ Project for Statistical Computing, 2019). EFA with dataset rawfl, method is maximum likelihood, diagonals of the correlation matrix are equal to squared multiple correlations. PA test is carried out to compute the eigenvalues for the correlation matrix. The plot the values from largest to smallest are shown on

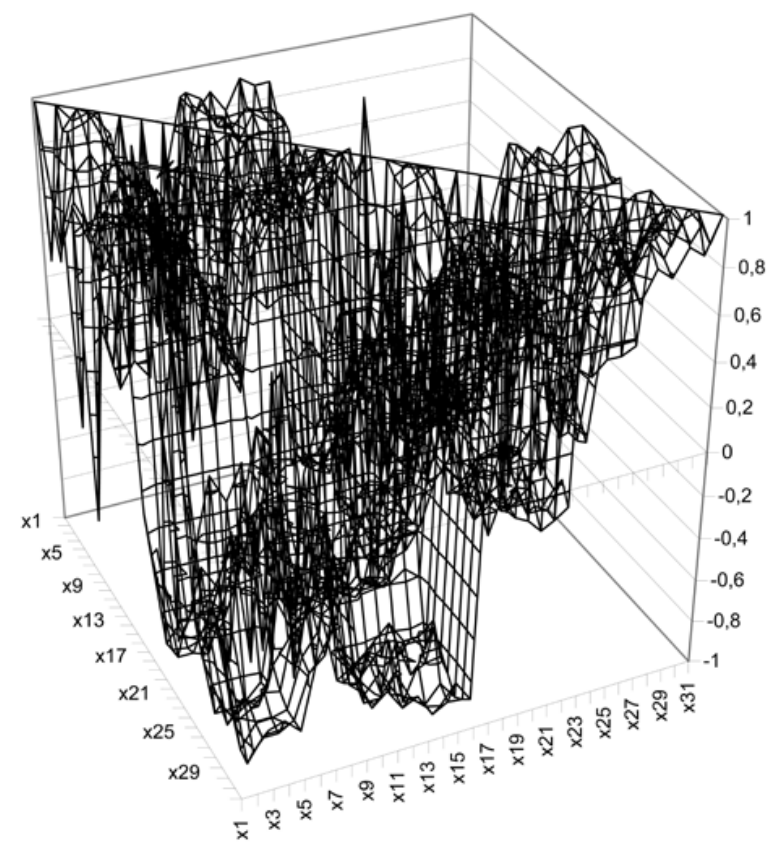

Figure 2. NRI indicators correlation matrix

Source: developed by the authors 


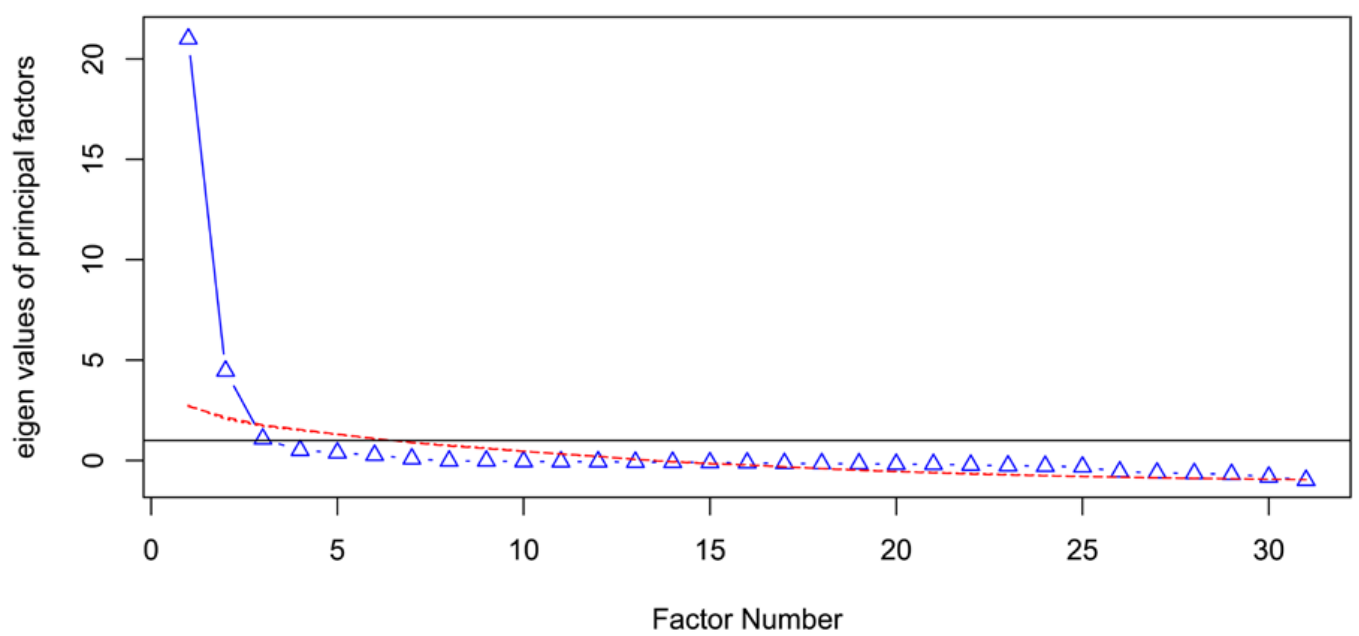

Figure 3. Factor analysis screen plots

Source: developed by the authors

Figure 3. The number of eigenvalues before the intersection point indicates three factors to include in your model. Eigenvalues of factors are shown values more than 1 on Figure 3.

The Eigenvalue criteria is the most used approach for the number of factors to be extracted. In this method, Eigenvalue is plotted on a graph and factors are selected.

Loadings of the factor with three largest are numerical values that indicate the strength and direction of these factor on a measured variable NRI. That is, the obtained values of factor loadings indicate how strongly the factor influences the measured variable.

\section{Conclusions}

Data dependency estimation for the macroeconomically significant Network readiness index has been implemented. It is proposed to construct a space of constituent parameters. Eigenvectors have been obtained for an array of data for the economies of eight European countries, which allow us to estimate the general development trends for macroeconomic decision-making problems. In particular, three complex factors are identified. They determine the change of constructs the value the Networked Readiness Index of countries. Proposed algorithm is proved improving of discriminating between indicators in construct of the value the Networked Readiness Index.

The conducted factor analysis is important for Ukraine in terms of planning for further development of information technologies. The intensification of the transition of state and business structures to the online mode is about to take place. Based on the global economic and social trends identified in the study, we predict that by April 2020, the world will intensify the use of information technology by almost three times. This will be caused by the global economic recession, triggered by the severe administrative restrictions on the rights and freedoms of the people and organizations from a viral pandemic COVID 19 that has begun to spread globally since late 2019 . We believe that as a result of such an external imperative and the actions of the national governments of the countries of the world, already in 2021, the users of information technologies will increase significantly and almost all organizations that survive after this economic recession will have an obligatory component of online technologies in operation management.

In an information society environment that is increasingly pushing society to move to the virtual space, most countries in the world already have strategies in place for integrating government and business processes into digital technology. Ukraine needs to intensify its analytical work on the systematic monitoring of economic and social factors that affect the country's ability to take advantage of modern information and communication technologies.

Future developments in this area of research may be to improve the methodology of assessing Ukraine's Network Readiness Index, based on a more thorough analysis of the most influential economic indicators of such economic changes in the European countries.

\section{References:}

"INSEAD's Endowment" (2019). INSEAD. Retrieved from: https://annual-report.insead.edu/finances-andendowment

Baller, S., Dutta, S., \& Lanvin, B. (2016). Insight Report The Global Information Technology Report 2016 Innovating in the Digital Economy. World Economic Forum, Geneva. 
Balzaravičienè1, S., \& Pilinkienè, V. (2012). Comparison and review of competitiveness indexes: towards the EU policy. Economics and Management, vol. 17(1), pp. 103-109.

Bilbao-Osorio, B., Dutta, S., \& Lanvin, B. (2013). Insight Report The Global Information Technology Report 2013 Growth and Jobs in a Hyperconnected World. World Economic Forum, Geneva.

Bilbao-Osorio, B., Dutta, S., \& Lanvin, B. (2014). Insight Report The Global Information Technology Report 2014 Rewards and Risks of Big Data. World Economic Forum, Geneva.

Cámara, N., \& Tuesta, D. (2017). DiGiX: The Digitization Index. Working Paper, 17/03. Retrieved from: https://www.bbvaresearch.com/wp-content/uploads/2017/02/WP_17-03_DiGiX_methodology.pdf

Degerli, A., Autekin, C., \& Degerli, B. (2015). Analyzing Information Technology Status and Networked Readiness Index in Context of Diffusion of Innovations Theory. Procedia - Social and Behavioral Sciences, vol. 195, pp. 1553-1562. Retrieved from: https://www.sciencedirect.com/science/article/pii/S1877042815036691

Digital Economy Report (2019). Value creation and capture: implication for developing countries. Retrieved from: https://unctad.org/en/pages/PublicationWebflyer.aspx?publicationid=2466

Dutta, S., Geiger, T., \& Lanvin, B. (2015). Insight Report The Global Information Technology Report 2015 ICTs for Inclusive Growth. World Economic Forum, Geneva.

Florenz, C. (2012). Tugas Enhancing Competitiveness: A Study on Income Level Groups and Networked Readiness Index. American International Journal of Contemporary Research, vol. 2(6), pp. 20-28. Retrieved from: http://www.aijcrnet.com/journals/Vol_2_No_6_June_2012/3.pdf

Mohammeda, F., \& Ibrahima, O. (2013). Refining E-government Readiness Index by Cloud Computing. Jurnal Teknologi (Sciences \& Engineering), vol. 65(1), pp. 23-34. Retrieved from: https://pdfs.semanticscholar.org/ f6a4/633c4e1d7b6fcde707e6d419f88c6f7c052d.pdf

Moroz, M. (2017). The Level of Development of the Digital Economy in Poland and Selected European Countries: A Comparative Analysis. Foundations of Management, vol. 9, pp. 175-190. doi: 10.1515/fman-2017-0014

Pasieczny, J., \& Sitnicki, M. (2019). Causes and consequences of organizational mismatches. Scientific Papers of Silesian University of Technology. Organization and Management Series, vol. 136, pp. 457-470. doi: 10.29119/16413466.2019.136.35

Petkova, L., Ryabokon, M., \& Vdovychenko, Y. (2019). Modern Systems for Assessing The Informatization Of Countries In The Context Of Global Sustainable Development. Baltic Journal of Economic Studies, vol. 5, no 2, pp. 158-170. doi: 10.30525/2256-0742/2019-5-2-158-170

Sitnicki, M. (2018). Development of a Model of Digital Research Universities. Baltic Journal of Economic Studies, vol. 4, no 1, pp. 311-318. doi: 10.30525/2256-0742/2018-4-1-311-318

Sitnicki, M. (2018a). Determining the Priorities of the Development of EU Research Universities Based on the Analysis of Rating Indicators of World-Class Universities. Battic Journal of European Studies, vol. 8, no 1(24), pp. 76-100. doi: 10.1515/bjes-2018-0006

Strohmaier, R., Schuetz, M., \& Vannuccini, S. (2019). A systemic perspective on socioeconomic transformation in the digital age. Journal of Industrial and Business Economics, vol. 46(3), pp. 361-378. doi: 10.1007/s40812-01900124-y

The R Project for Statistical Computing (2019). Retrieved from: https://www.r-project.org

World Bank Open Data (2016). Retrieved from: https://data.worldbank.org

Zhylinska, O., Sitnicki, M., \& Vikulova, A. (2019). Systematic Assessment of Innovative Potential of a Research University. Baltic Journal of Economic Studies, vol. 5, no 2, pp. 38-44. doi: 10.30525/2256-0742/2019-5-2-38-44

Chmeruk, H. (2018). The Level Of Digital Economy Development In Ukraine: Comparative Analisys By Index Of Networking Readiness. Synthesis of science and society in solving global problems - Shioda GmbH: 15-22. 